\title{
Hydrological Analysis and Peak Discharge Determination
}

\author{
Ebissa G. K. \\ M-Tech. Civil Engineering Department Indian Institute of Technology Roorkee
}

\begin{abstract}
Peak discharge Determination is one of the most important studies for Irrigation projects. The proposed of hydrologic design is to estimate maximum, average or minimum flood which the structure is expected to handle. This estimate has to be made quite accurately in order that the project can function properly. To estimate the magnitude of a flood peak the following alternative methods are available academically. In this study Hydrological analysis has been conducted based on 10years maximum daily rainfall data .The frequency analysis has been carried out by different methods and Log Pearson type III method is adopted .The peak discharge computed by United States Soil Conservation Service (USSCS) method is $1278 \mathrm{~m}^{3} / \mathrm{sec}$. Since this method over estimates the design flood, we adopt the peak discharge calculated by slope -area method.
\end{abstract}

Key Words: Hydrological Analysis, peak discharge Determination, Gusha Temela Irrigation project, frequency Analysis, United States of soil conservation service method.

\subsection{General}

\section{Introduction}

Ethiopia is situated in the horn of Africa, and is bordered by Sudan, Kenya, Somalia, Djibouti and Eritrea. The surface area is more than one million square kilometers and the country stretches from latitude $3^{\circ}$ North to latitude $15^{\circ}$ North of the equator and from $33^{\circ}$ East to $48^{\circ}$ East longitudes (MoWR, 2004). It has a large population of approximately 77.1 million people with an annual growth rate of $2.4 \%$ (FAO, 2008). The country has nine regional governments, Tigray, Afar, Amhara, Oromia, Somalia, Benshangul-Gumuz, Southern Nations Nationalities and Peoples, Gambella, Harari and two city states Addis Ababa and Dire Dawa. Ethiopia belongs to one of the poorest African countries, with $52 \%$ of the population living below the national poverty line (MoWR, 2004) and 31.3\% of the population living below US\$1 a day (World Bank in Teshome, 2003 p.24). Irrigation development plays an essential role in stabilizing crop production by either supplementing or replacing the need for natural precipitation. Irrigation makes agriculture more confidential. It stabilizes crop production by protecting against drought and by increasing crop yields, increases their income and crops that improve their diet Ebissa G. K. (2017). Despite the huge potential of the area, existing traditional farming practice is not in harmony with the needs and requirements of developing a productive and sustainable agriculture in Ethiopia. The food security situation has continued to deteriorate because of various factors including shortage of rain fall, high population growth, deforestation, soil degradation, pest out break and other related factors are threatening food security situation of the area. Although the initiation of farmer's traditional surface irrigation practice is appreciated, it is not in a position to provide sustainable supply source and effective utilization of water. Therefore, the development of Nanno Small Scale Irrigation Project diversion irrigation is expected to contribute towards alleviating these problems thereby increasing food supply and income source to the community and also at local and regional levels (Ebissa G. K. et al 2017). Fortunately, Ethiopia is lucky in that it has got ample source of surface and subsurface water for which it is known as "The Water Tower of East Africa." Moreover; the irrigation potential is estimated to be about 4.25 million hectare of which only $5.8 \%$ is irrigated.(source: Study carried out by International Water Management InstituteIWMI). Nowadays, implementation of small and medium scale irrigation schemes is being given priority in the water sector development strategy of Ethiopia.

\subsection{Back Ground}

Gusha Temela small-scale irrigation project is located in Arsi zone, in Digalo- Tijo district, which comprises 23 peasant associations (PA's) and three towns. The project area is especially located in the three adjacent PA's. Namely Gusha Temela, Chefe Gogessa and Ashebeka Walkitiel. The project area is accessible at $7 \mathrm{~km}$ from Sagure town towards South direction on the main gravel road of Assela-Bale Robe towns. Based on the information from the report by OIDA total area of the district is about $1349.26 \mathrm{~km}^{2}$ of which $31.3 \%$ is arable land. The soil type in the district: clay soil $35 \%$, loam soil $21 \%$ and red soil $44 \%$.The midland and highland (about $78 \%$ ) are the two major climate zones. So the project area is climatically categorized under highland. The altitude ranges $2000-3600 \mathrm{~m}$. a.m.s.l and temperature varies with in $15^{\circ} \mathrm{c}$ to $20^{\circ} \mathrm{c}$ while annual rainfall ranges from $900-1400 \mathrm{~mm}$. 
As indicated on the report the area for PA's were about 5567ha. And it could be understood that out of this $82.77 \%$ was cultivated under different annual crops, $1.82 \%$ was used as grazing area and the rest is utilized for different purposes The farmers practiced mixed type of farming. They are cultivating wheat, barely, bean, pea, and lin-seed (Telba). The beneficiary households are about 350 with total population of 2087 with average family size of six people per household.

The predominant crops grown in the project area; wheat, barely and lin-seed under rain-fed crop production. By traditional irrigation system 82 house holds were cultivating about 33.15 ha of land by diverting Temala River which is the potential river used for irrigation and the major crops grown by traditional Irrigation system are: potato, onion, cabbage and pepper. The following major constraints and problems were identified with regard to crop production under irrigated agriculture.

$>$ Low input use due to its higher price or weak economic condition of farmers to Purchase input at prevailing market price.

$>$ The use of traditional way of farming tools style under existing farming Practices.

$>$ No modern diversion work.

$>$ Poor supply canals with high seepage loss.

$>$ In appropriate water application to the crops

\subsection{Objectives}

The main objective of this study is to upgrade the existing traditional scheme in the area so that food shortage problem will be alleviated. The project will lead farmers to increase the income of the people. It helps the community to utilize the available resources more wisely and to avoid conflict among users. Therefore, the following points are the aim of the study:

$>$ To Analyze Hydrological data,

$>$ To determine peak discharge,

$>$ To calculate the peak flood,

$>$ To Calculate lean Flow ....etc.

\subsection{Methodologies}

In this study Hydrological analysis has been conducted based on 10years maximum daily rainfall data .The frequency analysis has been carried out by different methods. The peak discharge is computed by United States Soil Conservation Service (USSCS) method. Since this method over we estimate the design flood, the peak discharge by slope -area method. The methods followed in carrying out the above objectives are:

$>$ The frequency analysis has been carried out by different methods.

$>$ The peak discharge is computed by United States Soil Conservation Service (USSCS) method

$>$ Analysis of secondary data such as rain fall, hydrological,... etc.

$>$ Use of meteorological data to calculate the peak flood

$>$ Referring of different literature reviews and guidelines related to the study.

$>$ Use of contour map of the command area to read the weir length.

$>$ Use of topography map (1:50,000 scale) to determine the catchment characteristics

\subsection{General}

\section{Results and Discussions}

Hydrologic design is important for safety, economy and proper functioning of hydraulic structures. The proposed of hydrologic design is to estimate maximum, average or minimum flood which the structure is expected to handle. This estimate has to be made quite accurately in order that the project can function properly.

\section{Data availability}

All water resources system must be planned for future event for which the exact time of occurrence can be forecasted. In order to forecast the hydrological events, data is necessary. The available data is daily maximum rain fall of 10 years and mean monthly flow of the river Gusha Temela.

\subsection{Calculation of peak discharge}

To estimate the magnitude of a flood peak the following alternative methods are available academically.

1 Rational method

2 Empirical method

3 Slope area method

4 Flood frequency analysis or USSCS (United State Soil Conservation Service) method.

5 Stream flow measurement method 
The use of particular method depends upon:

$>$ The desired objective

$>$ The available data

$>$ The importance of the project

The size of the catchments

\subsubsection{Rational Method}

The rational formula is found to be suitable for peak flow prediction in small catchments up to $50 \mathrm{Km}^{2}$ in area. It is applicable in urban drainage design and in the design of small culverts and bridges. The equation of rational method is given by

$\mathrm{Q}_{\mathrm{P}}=\frac{1}{3.6} \mathrm{C} . \mathrm{I}_{\mathrm{tc}, \mathrm{p}} \cdot \mathrm{A}$

Where $Q_{P}=$ Peak discharge $\left(\mathrm{m}^{3} / \mathrm{sec}\right)$

$\mathrm{C}=$ Coefficient of run off

$\mathrm{A}=$ Drainage area in $\mathrm{Km}^{2}$

$\mathrm{I}_{\mathrm{tc}, \mathrm{p}}=$ the mean intensity of precipitation $(\mathrm{mm} / \mathrm{hr}$.) for

duration equal and an exceedance probability $\mathrm{p}$.

$\mathrm{I}_{\mathrm{tc}, \mathrm{p}}=\mathrm{R} 50 / \mathrm{Tc}=315.5 / 2.114=149.2 \mathrm{~mm} / \mathrm{hr}$.

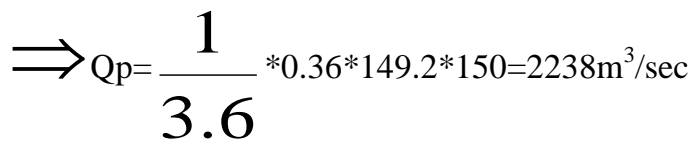

The use of this method to compute $Q_{P}$ requires three parameters ; $t_{c,}\left(I_{t c, p}\right)$ and $C$.

Rational method is not convenient for he determination of peak flood for river like Temela.

$>$ Estimation of $\mathrm{I}_{\mathrm{tc}, \mathrm{p}}$ requires some other regional constants based on catchment size difference.

\subsubsection{Empirical Formula}

The empirical formula used for the estimation of peak flood are essentially regional formula based on statistical correlation of the observed peak and important catchment properties. To simplify the form of the equation, only a few of the many parameters affecting the flood peak are used. For example almost all formulae use the catchment area as a parameter affecting the flood peak and most of them neglect the flood frequency as a parameter. In view of these the empirical formula are applicable only in the region from they were developed.

E.g. Dr Admassu's empirical formula is one of the applicable for some parts of Ethiopia

$\mathrm{Qp}=\mathrm{Q}(1+\mathrm{Kz} . \mathrm{Cv}) \quad$ (2 ) ......General formula

$\mathrm{Q}=0.87 \mathrm{~A}^{0.7}$

Where

$\mathrm{A}=$ catchments area $\left(\mathrm{Km}^{2}\right)$

$\mathrm{Kz}=$ Frequency factor

$=\frac{-\sqrt{6}}{\pi}\left[0.57721+\ln \left(\ln \left(\frac{\boldsymbol{T}}{T-1}\right)\right)\right]$

$\mathrm{T}=$ Return period

$\mathrm{Cv}=$ The average coefficient of variation.

$=0.38$ for most catchment.

$\mathrm{Qp}=\mathrm{Q}(1+\mathrm{Kz} . \mathrm{Cv})$

$=57.63 \mathrm{~m}^{3} / \mathrm{sec}$

The formula is safely adopted for Blue Nile basin under the given area range. However, the water shed of Temela river is out of domain and hence we didn't adopt the result for this method.

\subsubsection{Slope Area Method}

According to the given parameters

Cross sectional area $(\mathrm{A})=98 \mathrm{~m}^{2}$

Wetted perimeter $(\mathrm{P})=36 \mathrm{~m}$

Hydraulic radius $(\mathrm{R})=2.7$

Water surface slope $(\mathrm{S})=0.004$

Manning roughness $(\mathrm{n})=0.04$ 
From manning equation

$\mathrm{V}=\underline{1} * \mathrm{R}^{2 / 3} * \mathrm{~S}^{1 / 2}$

$n$

$=3 \mathrm{~m} / \mathrm{sec}$

$\mathrm{Q}=\mathrm{V} * \mathrm{~A}$

$=290 \mathrm{~m}^{3} / \mathrm{sec}$ (Source OIDA report)

\subsubsection{Frequency Analysis (United State Soil Conservation Service) Method}

Testing For Out Lairs

Out lairs are data point that depart significantly from the trend of the remaining data. The depletion of high and low out lair can one sided $10 \%$ significantly affect the magnitude of statistical parameter computed data. Specially for small number data to find lower and higher out lairs. The following equation is used.

Lower out lairs $(\mathrm{XL})=\bar{X}-\mathrm{Kn} * \delta_{\mathrm{X}}$

$\Rightarrow \mathrm{Q}_{\mathrm{L}}=10^{\mathrm{XL}}$

Higher out lairs $(\mathrm{XL})=\bar{X}+\mathrm{Kn} * \delta_{\mathrm{X}}$

$\Rightarrow \mathrm{Q}_{\mathrm{H}}=10^{\mathrm{XH}}$

Where $\bar{X}=$ Mean value of logarithm transferred

data.

$\mathrm{Kn}=$ factor taken from table which contains

one side $10 \%$ significance

$\delta_{\mathrm{X}}=$ Standard deviation of logarithmic

transferred data.

$\mathrm{Q}_{\mathrm{L}}=$ The lower discharge

$\mathrm{Q}_{\mathrm{H}}=$ The higher discharge

$\mathrm{Kn}=2.036$ (V.T.Chow, 1988)

$\bar{X}=2.30126, \delta \mathrm{x}=0.0604$

$\Leftrightarrow \mathrm{X}_{\mathrm{L}}=\bar{X}-\mathrm{Kn} * \delta_{\mathrm{X}}$

$=2.30126-2.036 * 0.0604$

$=2.1785$

$\Rightarrow \mathrm{Q}_{\mathrm{L}}=10^{\mathrm{XL}}$

$=150.83 \mathrm{~mm}$ (Lower margin)

$\Leftrightarrow \mathrm{X}_{\mathrm{L}}=\bar{X}+\mathrm{Kn} * \delta_{\mathrm{X}}$

$=2.30126+2.036 * 0.0604$

$=2.4244$

$\Rightarrow \mathrm{Q}_{\mathrm{L}}=10^{\mathrm{XL}}$

$=265.705 \mathrm{~mm}$ (upper margin)

Therefore, the data that is available from the OIDA report checked for further analysis between the lower and the higher value obtained from the calculation.

\section{Rain fall frequency analysis}

Some of the commonly used frequency distribution function for the prediction of extreme maximum rain fall values are:

1. Normal distribution method.

2. Gumbel distribution method.

3. Log Pearson type III distribution method.

4. Log normal distribution method.

5. Pearson type distribution method.

Taking return period of 50 years (Dr. Mr. Suberamanya,1989) the design rain fall is determined as follows. 


\subsubsection{Normal Distribution Method}

$\mathrm{X}_{\mathrm{T}}=\bar{X}+\mathrm{K}_{\mathrm{T}} * \delta_{\mathrm{n}-1} \quad(5)$

Where $X_{\mathrm{T}}=$ annual maximum rain fall of $\mathrm{T}$ year return period

$\bar{X}=$ mean of annual maximum daily rain fall

$\mathrm{K}_{\mathrm{T}}=$ frequency factor expressed as

$\mathrm{K}_{\mathrm{T}}=\mathrm{W}-\left(\frac{2.51557+0.80285 W+0.01033 W^{2}}{1+1.143279 W+0.1992 W^{2}+0.00135 W^{3}}\right)$

$\Rightarrow \mathrm{W}=\left(\ln \left(1 / \rho_{\mathrm{r}}\right)^{2}\right)^{1 / 2}, \quad \rho_{\mathrm{r}}=\frac{1}{T}$

$\Rightarrow \rho_{\mathrm{r}}=\frac{1}{50}=0.02$

$\left.\mathrm{W}=\ln (1 / 0.02)^{2}\right)^{1 / 2}$

$=2.797$

$\mathrm{K}_{\mathrm{T}}=2.06276=2.063$

$\mathrm{X}_{50}=\bar{X}+2.063 * \delta_{\mathrm{n}-1}$

$=202.16+2.063 * 29.0759=262.143 \mathrm{~mm}$

\subsubsection{Gumbel Distribution Method}

It is one of the widely used probability distribution function for extreme values in hydrologic and metrological studies for prediction of flood peaks, maximum rain falls, wind speed etc. and expressed by equation .

$\mathrm{RT}=\bar{R}+\mathrm{K} \sigma_{R}-1 \quad(6)$

Where $\mathrm{RT}=$ annual maximum rain fall of $\mathrm{T}$ years return period

$\bar{R}=$ mean of the annul maximum daily rain fall.

$\mathrm{K}=$ frequency factor and expressed as

$\mathrm{K}=\frac{Y_{T}-\overline{Y n}}{S n}$

$\sigma_{R}-1=$ standard deviation of the sample size

$\mathrm{N}=\sqrt{\frac{\sum(R-\bar{R})}{N-1}}$

Let $\mathrm{Y}_{\mathrm{T}}$ be a reduced variety, a function of $\mathrm{T}$ and is given by

$\mathrm{Y}_{\mathrm{T}}=-\ln \left(\ln \left(\frac{T}{T-1}\right)\right)$

Where $\overline{Y_{n}}=$ reduced mean, it is a function of sample size

$\mathrm{Sn}=$ reduced standard deviation which is also a function of the sample size $\mathrm{Yn}$ and $\mathrm{Sn}$ are obtained from table.

This equation are used under the following procedure to estimate the rain fall magnitude corresponding to a given return period based on the maximum daily rain fall series.

Assemble the maximum daily rain fall data and note the sample size $\mathrm{N}$.

Here the rain fall data is the variete $\bar{R}$. Find $\bar{R}$ and $\sigma_{R}-1$ for the given data .

$>$ Using table determine $\mathrm{Yn}$ and $\mathrm{Sn}$ appropriate to given $\mathrm{N}$

$>$ Find $\mathrm{Y}_{\mathrm{T}}$ for a given $\mathrm{T}$ by equation (9)

$>$ Find $\mathrm{K}$ by equation (7)

$>$ Determine the required $\mathrm{R}_{\mathrm{T}}$ by equation (6) 
Table 1 Determination of design storm arranging the maximum values in descending order.

\begin{tabular}{|c|c|c|c|c|}
\hline S.No & $\begin{array}{l}R(\mathbf{m m}) \text { in descending } \\
\text { order }\end{array}$ & $\bar{R}(\mathrm{~mm})$ & $\begin{array}{l}\mathbf{R}-\bar{R} \\
(\mathbf{m m})\end{array}$ & $(\mathrm{R}-\bar{R})^{2}$ \\
\hline 1 & 249 & \multirow{10}{*}{202.16} & 46.86 & 2193.986 \\
\hline 2 & 228.7 & & 26.54 & 704.3716 \\
\hline 3 & 225 & & 22.84 & 521.6656 \\
\hline 4 & 213.2 & & 11.04 & 121.8816 \\
\hline 5 & 206.7 & & 4.54 & 20.6116 \\
\hline 6 & 202 & & -0.16 & 0.0256 \\
\hline 7 & 200 & & -2.16 & 4.6656 \\
\hline 8 & 170.6 & & -31.56 & 996.0336 \\
\hline 9 & 165.4 & & -36.76 & 1351.1976 \\
\hline 10 & 161 & & -41.16 & 1694.14 \\
\hline$\sum$ & 2021.6 & \multicolumn{2}{|l|}{$\sum$} & 7608.579 \\
\hline
\end{tabular}

$\bar{R}=\frac{\sum_{i=1}^{n} R_{i}}{n}=\frac{2021.6}{10}=202.16$

$\sigma_{R}-1=\sqrt{\frac{\sum_{i=1}^{n}\left(R_{i}-\bar{R}\right)^{2}}{N-1}}=\sqrt{\frac{7608.579}{9}}=29.075$

Now, $\mathrm{KT}=\frac{\boldsymbol{Y}_{\boldsymbol{T}}-\boldsymbol{Y} \boldsymbol{n}}{\operatorname{Sn}}, \quad$ where $\mathrm{YT}=-\ln \left(\ln \left(\frac{T}{T-1}\right)\right)$, For $\mathrm{T}=50$

$\mathrm{Y}_{\mathrm{T}}=-\ln (\ln (50 / 49))$

$\mathrm{Y}_{\mathrm{T}}=3.952$

Yn $=0.49$ (Refer table 3.3 in the annex 3$)$

$\mathrm{Sn}=0.9496 \quad$ (Refer table 3.2 in the annex 3$)$

$\Rightarrow \mathrm{KT}=3.587$

So $\quad \mathrm{R}_{\mathrm{T}}=\bar{R}+\mathrm{K}_{\mathrm{T}} \sigma_{R}-1$

$=202.16+3.587 * 29.075$

$=315.55 \mathrm{~mm}$

\subsubsection{Log Person Type III Distribution Method.}

In this method the verity is first transformed into logarithmic form (base 10 ) and the transformed data is then analyzed. If $\mathrm{R}$ is the verity of random hydrologic series then the series of $\mathrm{Z}$ varieties where $\mathrm{Z}=\log \mathrm{R} \quad(10)$

are obtained, for this $\mathrm{Z}$ series for any recurrence interval $\mathrm{T}$.

$\mathrm{Z}_{\mathrm{T}}=\bar{Z}+\mathrm{K}_{\mathrm{Z}} \sigma_{R} \quad(11)$

Where $\mathrm{KZ}=\mathrm{a}$ frequency factor which is a function of $\mathrm{T}$

and the coefficient of skew ness, $\mathrm{C}_{\mathrm{S}}$.

$\sigma_{R}=$ standard deviation of the $\mathrm{Z}$ verity sample

$=\sqrt{\frac{\sum(Z-\bar{Z})^{2}}{N-1}}$

$\mathrm{C}_{\mathrm{s}}=\frac{N \sum(Z-\bar{Z})^{3}}{(N-1)(N-2)\left(\sigma_{z}\right)^{3}}$

Where

$\bar{Z}=$ mean of the value

$\mathrm{N}=$ sample size $=$ number of years of record

The variation of $\mathrm{K} 2=\mathrm{f}\left(\mathrm{C}_{\mathrm{S}}, \mathrm{T}\right)$ is given in table 3.4 in the annex 3 . 
First find ZT by equation (11)

$\begin{array}{lllll}\text { Then } & \text { find } & \mathrm{R}_{\mathrm{T}} & \text { by } & \text { equation }\end{array}$

Table 2 Calculation of design storm by $\log$ Pearson typeIII.

\begin{tabular}{|c|c|c|c|c|c|}
\hline S.No. & $\begin{array}{l}\text { Max. daily rain } \\
(\mathrm{mm})\end{array}$ & $Z=\log R$ & $\bar{Z}$ & $\mathrm{Z}-\bar{Z}$ & $(\mathrm{Z}-\bar{Z})^{3}$ \\
\hline 1 & 249 & 2.396 & \multirow{10}{*}{2.3015} & 0.095 & $8.36 * 10^{-4}$ \\
\hline 2 & 228.7 & 2.359 & & 0.058 & $1.90 * 10^{-4}$ \\
\hline 3 & 225 & 2.352 & & 0.050 & $1.26 * 10^{-4}$ \\
\hline 4 & 213.2 & 2.329 & & 0.026 & $1.92 * 10^{-5}$ \\
\hline 5 & 206.7 & 2.315 & & 0.013 & $2.37 * 10^{-6}$ \\
\hline 6 & 202 & 2.305 & & 0.003 & $3.76^{*} 10^{-8}$ \\
\hline 7 & 200 & 2.301 & & -0.001 & $-9.13 * 10^{-10}$ \\
\hline 8 & 170.6 & 2.232 & & -0.070 & $-3.40^{*} 10^{-4}$ \\
\hline 9 & 165.4 & 2.219 & & -0.083 & $-5.72 * 10^{-4}$ \\
\hline 10 & 161 & 2.207 & & -0.0947 & $-8.49 * 10^{-4}$ \\
\hline$\sum$ & 2021.6 & 23.02 & & -0.0045 & -0.021 \\
\hline
\end{tabular}

$$
\begin{aligned}
& \bar{Z}=\sum_{i=1}^{n} Z=2.3015 \sigma_{R}=\frac{\sqrt{\sum(z-\bar{z})^{2}}}{\sqrt{(N-1)}}=0.0604 \\
& \mathrm{C}_{\mathrm{S}}=\frac{N \sum(Z-\bar{Z})^{3}}{(N-1)(N-2)\left(\sigma_{z}\right)^{3}}=\frac{10 *(-0.021)^{3}}{9 * 8 *(0.0604)^{3}}=-0.005837
\end{aligned}
$$

For $\mathrm{T}_{50}$ and $\mathrm{C}_{\mathrm{S}}=0.005837$ from table, $\mathrm{K}_{\mathrm{Z}}=2.05084$

$\mathrm{Z}_{50}=\bar{Z}+\mathrm{K}_{\mathrm{Z}} * \sigma_{R}$

$=2.3015+2.05084 * 0.0604=2.4253$

$\Rightarrow \mathrm{X}_{\mathrm{T}}=10^{2.4253}=266.19 \mathrm{~mm}$

\subsubsection{Log Normal Distribution}

Log normal distribution is a special type of Pearson type III distribution with $\mathrm{C}_{S}=0$ i.e. from table 3.4 in the annex 3.

For $\mathrm{C}_{\mathrm{S}}=0$ and $\mathrm{T}_{50} ; \mathrm{K}_{\mathrm{Z}}=2.054$

$\Rightarrow \mathrm{Z}_{50}=\bar{Z}+\mathrm{K}_{\mathrm{Z}} * \sigma_{R}$

$=2.3015+2.054 * 0.0604=2.425$

$\bar{X}=10^{2.42556}=266.4 \mathrm{~mm}$

\subsubsection{Pearson Type III Distribution Method}

$\mathrm{X}_{\mathrm{T}}=\bar{X}+\mathrm{K}_{\mathrm{T}} * \sigma_{n}-1$

$=202.16+2.05084 * 29.0759$

$=261.79 \approx 262 \mathrm{~mm}$

Testing the goodness of fitness of probability

The D-index for the computation of first fit of various distribution is given by :

D-index $=\frac{1}{\bar{X}} \sum_{i=1}^{5}|X i-X C|$

Where $\mathrm{Xi}$ and $\mathrm{Xc}$ are the $\mathrm{I}^{\text {th }}$ highest observed and computed values for the distribution. The distribution giving the least D-index is considered to be the best distribution

Table 3 Statistical Parameter

\begin{tabular}{|l|l|l|}
\hline & Original series & Log transformed \\
\hline Mean & 202.16 & 2.31 \\
\hline Standard deviation & 29.075 & 1.4635 \\
\hline
\end{tabular}


Table 4 Normal Distribution of Rainfall Data

\begin{tabular}{|l|l|l|l|l|l|l|}
\hline Rank & $\mathbf{X}_{\mathbf{i}}$ & $\mathbf{P}=\mathbf{m} /(\mathbf{n}+\mathbf{1})$ & $\mathbf{K t}$ & $\mathbf{X}_{\mathbf{C}}$ & $\mathbf{X}_{\mathbf{i}}-\mathbf{X c}$ & \\
\hline 1 & 249 & $1 / 11$ & 1.34 & 287.96 & 38.96 \\
\hline 2 & 228.7 & $2 / 11$ & 0.91 & 255.158 & 26.458 \\
\hline 3 & 225 & $3 / 11$ & 0.6 & 242.445 & 17.445 \\
\hline 4 & 213.2 & $4 / 11$ & 0.35 & 223.376 & 10.176 \\
\hline 5 & 206.7 & $5 / 11$ & 0.11 & 209.898 & 3.198 \\
\hline$\sum$ & & & 96.237 \\
\end{tabular}

$$
\begin{aligned}
& \mathrm{X}_{\mathrm{C}}=\mathrm{X}_{\mathrm{i}}+\mathrm{K}_{\mathrm{T}} \sigma_{n}-1 \\
& \mathrm{D}-\text { index }=\frac{\sum_{i=1}^{5}|X i-X c|}{\bar{X}}=\frac{96.237}{202.16}=0.476
\end{aligned}
$$

Table 5 Log Normal Distribution of Rainfall Data

\begin{tabular}{|c|c|c|c|c|c|c|}
\hline Rank & $\mathbf{X}_{\mathbf{i}}$ & $\mathbf{P}=\mathbf{m} /(\mathbf{n + 1})$ & $\mathbf{K t}$ & $\mathbf{X c}$ & $\mathbf{X i - X c}$ \\
\hline 1 & 2.396 & $1 / 11$ & 1.34 & 4.357 & 1.961 \\
\hline 2 & 2.359 & $2 / 11$ & 0.91 & 3.69 & 1.335 \\
\hline 3 & 2.352 & $3 / 11$ & 0.6 & 3.23 & 0.878 \\
\hline 4 & 2.328 & $4 / 11$ & 0.35 & 2.84 & 0.512 \\
\hline 5 & 2.315 & $5 / 11$ & 0.11 & 2.475 & 0.16 \\
\hline \multicolumn{7}{|r|}{} \\
\hline
\end{tabular}

$$
\begin{gathered}
\mathrm{X}_{\mathrm{C}}=\mathrm{X}_{\mathrm{i}}+\mathrm{K}_{\mathrm{T}} \sigma_{n}-1 \\
\mathrm{D}-\text { index }=\frac{\sum_{i=1}^{5}|X i-X c|}{\bar{X}}=\frac{4.842}{2.31}=2.096
\end{gathered}
$$

Table 6 Pearson Type III of Rainfall Data

\begin{tabular}{|c|c|c|c|c|c|}
\hline Rank & $\mathbf{X i}$ & $P=m /(n+1)$ & $\mathbf{K t}$ & $\mathrm{Xc}$ & $\mathrm{Xi}-\mathrm{Xc}$ \\
\hline 1 & 2.396 & $1 / 11$ & 1.328 & 4.34 & 1.944 \\
\hline 2 & 2.359 & $2 / 11$ & 0.805 & 3.54 & 1.181 \\
\hline 3 & 2.352 & $3 / 11$ & 0.495 & 3.076 & 0.724 \\
\hline 4 & 2.328 & $4 / 11$ & 0.252 & 2.696 & 0.368 \\
\hline 5 & 2.315 & $5 / 11$ & 0.0891 & 2.445 & 0.13 \\
\hline$\sum$ & & & & & 4.347 \\
\hline
\end{tabular}

\begin{tabular}{|l|l|l|l|l|l|l|}
\hline Rank & $\mathrm{Xi}$ & $\mathrm{P}=\mathrm{m} /(\mathrm{n}+1)$ & $\mathrm{Kt}$ & $\mathrm{Xc}$ & $\mathrm{Xi}-\mathrm{Xc}$ & \\
\hline 1 & 249 & $1 / 11$ & 1.328 & 287.61 & 38.61 \\
\hline 2 & 228.7 & $2 / 11$ & 0.805 & 252.12 & 23.42 \\
\hline 3 & 225 & $3 / 11$ & 0.495 & 239.39 & 14.39 \\
\hline 4 & 213.2 & $4 / 11$ & 0.252 & 220.52 & 7.32 & 2.59 \\
\hline 5 & 206.7 & $5 / 11$ & 0.0891 & 209.29 & 86.32 \\
\hline$\sum$ & & & \\
\hline
\end{tabular}

$$
\begin{aligned}
& \mathrm{X}_{\mathrm{C}}=\mathrm{X}_{\mathrm{i}}+\mathrm{K}_{\mathrm{T}} \sigma_{\boldsymbol{n}}-1 \\
& \mathrm{D}-\text { index }=\frac{\sum_{i=1}^{5}|\boldsymbol{X i}-\boldsymbol{X} \boldsymbol{c}|}{\bar{X}}=\frac{86.32}{202.16}=0.426
\end{aligned}
$$

Table 7 Log person Type III of Rainfall Data 
$\mathrm{X}_{\mathrm{C}}=\mathrm{X}_{\mathrm{i}}+\mathrm{K}_{\mathrm{T}} \boldsymbol{\sigma}_{\boldsymbol{n}}-\mathbf{1}$
$\mathrm{D}-$ index $=\frac{\sum_{\boldsymbol{i}=1}^{5}|\boldsymbol{X} \boldsymbol{i}-\boldsymbol{X} \boldsymbol{C}|}{\overline{\boldsymbol{X}}}=\frac{4.347}{2.31}=1.8818$

Table 8 Gamble Distribution Method

\begin{tabular}{|l|l|l|l|l|l|}
\hline Rank & $\mathbf{X i}$ & $\mathbf{P}=\mathbf{m} / \mathbf{( n + 1 )}$ & $\mathbf{K t}$ & $\mathbf{X c}$ & $\mathbf{I X i - X c ~ I ~}$ \\
\hline 1 & 2.396 & $1 / 11$ & 1.34 & 4.357 & 1.961 \\
\hline 2 & 2.359 & $2 / 11$ & 0.91 & 3.69 & 1.335 \\
\hline 3 & 2.352 & $3 / 11$ & 0.60 & 3.23 & 0.878 \\
\hline 4 & 2.328 & $4 / 11$ & 0.35 & 2.84 & 0.512 \\
\hline 5 & 2.315 & $5 / 11$ & 0.11 & 2.475 & 0.160 \\
\hline$\sum$ & & & 131.79 \\
\end{tabular}

$\mathrm{X}_{\mathrm{C}}=\mathrm{X}_{\mathrm{i}}+\mathrm{K}_{\mathrm{T}} \sigma_{\mathrm{n}}-1$

$\mathrm{D}-$ index $=\frac{\sum_{i=1}^{5}|\boldsymbol{X} \boldsymbol{i}-\boldsymbol{X} \boldsymbol{c}|}{\overline{\boldsymbol{X}}}=\frac{131.79}{202.16}=0.6519$

D-index is minimum incase of Pearson type III distribution and hence on the basis of D-index test it can be assumed that Pearson type III fits the data well.

Therefore, the design rainfall is $261.8 \mathrm{~mm}$.

Table 9 Peak Runoff calculations by United States Soil Conservation Service method

\begin{tabular}{|c|c|c|c|c|}
\hline Step & Formula & Symbol & unit & Result \\
\hline 1 & $\begin{array}{l}\text { Area of catchment (this can be determined from 1:50,000 scale topographical maps or } \\
\text { aerial photographs) }\end{array}$ & A & $\mathrm{Km}^{*} 2$ & 150 \\
\hline 2 & $\begin{array}{l}\text { Length of main water course from watershed divide to proposed diversion or storage } \\
\text { site (Topographic maps) }\end{array}$ & $\mathrm{L}$ & $\mathrm{m}$ & \\
\hline 3 & $\begin{array}{l}\text { Elevation of water shed divide opposite to the head of the main water } \\
\text { course(Topographic maps) }\end{array}$ & H1 & $\mathrm{M}$ & \\
\hline 4 & Elevation of stream bed at proposed or storage site (Topographic maps) & $\mathrm{H} 2$ & $\mathrm{~m}$ & \\
\hline 5 & $\mathrm{~S}=\frac{(H 1-H 2)}{L}$ & $\mathrm{~S}$ & $\mathrm{~m} / \mathrm{m}$ & \\
\hline 6 & $\begin{array}{l}\text { Time of concentration } \\
\mathrm{Tc}=\frac{1}{3000} *\left(\frac{L}{\sqrt{S}}\right) * 0.77\end{array}$ & Tc & $\mathrm{hr}$ & 2.114 \\
\hline 7 & $\begin{array}{l}\text { Rain fall excess duration } \\
\mathrm{D} \approx \frac{T c}{6}, \text { if } \mathrm{Tc}<3 \mathrm{hrs} . \\
\mathrm{D} \approx 1 \mathrm{hr}, \text { if } \mathrm{Tc}>3 \mathrm{hrs} .\end{array}$ & $\mathrm{D}$ & $\mathrm{hr}$ & 0.3523 \\
\hline 8 & $\begin{array}{l}\text { Time to peak } \\
t_{p}=0.5 \mathrm{D}+0.6 \mathrm{Tc}\end{array}$ & tp & $\mathrm{Hr}$ & 1.44 \\
\hline 9 & $\begin{array}{l}\text { Time base of hydrograph } \\
\mathrm{Tb}=2.67 \mathrm{t}_{\mathrm{p}}\end{array}$ & $\mathrm{Tb}$ & $\mathrm{hr}$ & 3.85 \\
\hline 10 & $\begin{array}{l}\text { Time lag } \\
\text { Te }=0.6 \mathrm{tc}\end{array}$ & $\mathrm{Te}$ & $\mathrm{hr}$ & 1.2684 \\
\hline 11 & $\begin{array}{l}\text { Peak rate of discharge created by } 1 \mathrm{~mm} \text { runoff excess on whole of the catchment } \\
t p\end{array}$ & $\mathrm{Qp}$ & $\begin{array}{l}\mathrm{M}^{*} 3 / \mathrm{S} . / \mathrm{m} \\
\mathrm{m}\end{array}$ & 21.875 \\
\hline
\end{tabular}




\begin{tabular}{|c|c|c|c|c|c|c|c|c|}
\hline 12 & 13 & 14 & 15 & 16 & 17 & 18 & \multicolumn{2}{|l|}{19} \\
\hline duration & $\begin{array}{l}\text { daily point } \\
\text { rainfall of } \\
\text { return period } \\
50 \text { year }\end{array}$ & $\begin{array}{l}\text { rainfall } \\
\text { profile }\end{array}$ & $\begin{array}{l}\text { rainfall } \\
\text { profile }\end{array}$ & $\begin{array}{l}\text { areal to point } \\
\text { rainfall }\end{array}$ & $\begin{array}{l}\text { areal } \\
\text { rainfall }\end{array}$ & $\begin{array}{l}\text { Increme-ntal } \\
\text { rainfall }\end{array}$ & \multicolumn{2}{|c|}{ descending order } \\
\hline $\mathrm{hr}$ & $\mathrm{mm}$ & $\%$ & $\mathrm{~mm}$ & $\%$ & $\mathrm{~mm}$ & $\mathrm{~mm}$ & No. & \\
\hline $0-0.35$ & \multirow[b]{6}{*}{261.8} & 26 & 68.07 & 57 & 38.8 & 38.8 & 1 & 38.80 \\
\hline $0.35-0.7$ & & 33 & 86.39 & 57.33 & 49.53 & 10.73 & 2 & 26.04 \\
\hline $0.7-1.05$ & & 46 & 120.43 & 62.75 & 75.57 & 26.04 & 3 & 12.13 \\
\hline $1.05-1.4$ & & 50 & 130.9 & 67 & 87.7 & 12.13 & 4 & 11.91 \\
\hline $1.4-1.75$ & & 55 & 143.99 & 67 & 96.47 & 8.77 & 5 & 10.73 \\
\hline $1.75-2.1$ & & 59 & 154.46 & 70.17 & 108.38 & 11.91 & 6 & 8.77 \\
\hline 12 & \multicolumn{8}{|c|}{ Fill in $0-\mathrm{D} \mathrm{hr}, \mathrm{D}-2 \mathrm{D} \mathrm{hr}, \ldots \ldots, 5 \mathrm{D}-6 \mathrm{D}}$. \\
\hline 13 & \multicolumn{8}{|c|}{ Determine the magnitude of the daily rainfall with the given recurrent interval by applying statistical method } \\
\hline 14 & \multicolumn{8}{|c|}{ Read from Table 6 (IVA-1/B.1) the rainfall profile(\%) occurring in D,2D,3D,...6Dhr.and enter in 14} \\
\hline 15 & \multicolumn{8}{|c|}{ Multiply 13and 14 to find the rainfall profile $(\mathrm{mm})$ and enter in 15.} \\
\hline 16 & \multicolumn{8}{|c|}{$\begin{array}{l}\text { Read from Table (IVA-1/B.1) aerial to point rainfall ratio for different duration and particular catchment area. (method based } \\
\text { on research conducted in India and influenced by return period, magnitude of storm shape and orientation of area etc. }\end{array}$} \\
\hline 17 & \multicolumn{8}{|c|}{ Multiply 15 and 16 and fill in 17.} \\
\hline 18 & \multicolumn{8}{|c|}{ Calculate incremental rainfall by deducting the current areal rainfall from the preceding areal rainfall as listed in 18 . } \\
\hline 19 & \multicolumn{8}{|c|}{ Assign order to the rainfall depths in descending order 1 and 6} \\
\hline
\end{tabular}

\begin{tabular}{|c|c|c|c|c|c|c|}
\hline 20 & 21 & 22 & 23 & & 24 & 25 \\
\hline \multirow{2}{*}{$\begin{array}{l}\text { Rearranged } \\
\text { order }\end{array}$} & \multirow{2}{*}{$\begin{array}{l}\text { Rearranged } \\
\text { incremental } \\
\text { rainfall }\end{array}$} & \multirow{2}{*}{$\begin{array}{l}\text { Cumulative } \\
\text { rainfall }\end{array}$} & \multicolumn{4}{|c|}{ Time of incremental hydrograph } \\
\hline & & & $\begin{array}{l}\text { Time of } \\
\text { beginning }\end{array}$ & $\begin{array}{l}\text { Time to } \\
\text { peak }\end{array}$ & \multicolumn{2}{|l|}{ Time to end } \\
\hline $\mathrm{NO}$ & $\mathrm{mm}$ & $\mathrm{mm}$ & $\mathrm{hr}$ & $\mathrm{hr}$ & \multicolumn{2}{|l|}{$\mathrm{hr}$} \\
\hline 6 & 8.77 & 8.77 & 0 & 1.44 & \multicolumn{2}{|l|}{3.85} \\
\hline 4 & 11.91 & 20.68 & .35 & 1.79 & \multicolumn{2}{|l|}{4.21} \\
\hline 3 & 12.13 & 32.81 & .7 & 2.14 & \multicolumn{2}{|l|}{4.56} \\
\hline 1 & 38.8 & 71.61 & 1.05 & 2.49 & \multicolumn{2}{|l|}{4.91} \\
\hline 2 & 26.04 & 97.65 & 1.4 & 2.84 & \multicolumn{2}{|l|}{5.26} \\
\hline 5 & 10.73 & 108.38 & 1.75 & 3.19 & \multicolumn{2}{|l|}{5.6} \\
\hline 20 & \multicolumn{6}{|c|}{$\begin{array}{l}\text { From } 19 \text { mention the rearranged order as } 6,4,3,1,2,5 \text { (arbitrary but considering ascending and descending } \\
\text { feature of the hydrograph ordinates, where peak value is around the middle of the hydrograph. }\end{array}$} \\
\hline 21 & \multicolumn{6}{|c|}{ Fill in the corresponding incremental rainfall value to the rearranged order of 20 from 18.} \\
\hline 22 & \multicolumn{6}{|c|}{ Fill in the cumulative rainfall values of 21 by adding with the rainfall values in the preceding duration. } \\
\hline 23 & \multicolumn{6}{|c|}{ Fill in the time of beginning of hydrograph as $0, \mathrm{D}, 2 \mathrm{D}, \ldots .5 \mathrm{Dhr}$} \\
\hline 24 & \multicolumn{6}{|c|}{ Fill the time to peak as tp, D+tp, 2D+tp, ...5D+tp or add tp in every value of 23 and mention in 24 . } \\
\hline 25 & \multicolumn{6}{|c|}{ Add tp in every value of 23 and fill in 25} \\
\hline
\end{tabular}

\begin{tabular}{|c|c|c|c|c|}
\hline NO & Formula & symbol & unit & result \\
\hline 32 & $\begin{array}{l}\text { Find maximum potential difference between rainfall(p) and direct } \\
\text { runoff(Q), which is given by the following formula: } \\
\mathrm{S}=\frac{25400}{\mathrm{CN}}-254 \\
\mathrm{CN}=\text { value corresponding to AMC III as found in } 31\end{array}$ & $\mathrm{~S}$ & $\mathrm{~mm}$ & 27.28 \\
\hline 33 & $\begin{array}{l}\text { Substitute the value of "S" in the following formula, giving the relation } \\
\text { between direct runoff }(\mathrm{Q}) \text { and rainfall }(\mathrm{P}) \\
\mathrm{Q}=(P-0.2 S) 2\end{array}$ & Q & $\mathrm{mm}$ & $\mathrm{Q}=\frac{(P-5.56)}{(P+21.82)}$ \\
\hline \multirow[t]{8}{*}{34} & \multirow{8}{*}{$\begin{array}{l}\text { Substitute the value of } \mathrm{p} 1 \text { as mentioned in } 22 \text {,in the above formula and find } \\
\text { the corresponding values of } \\
\mathrm{Q}(34) \\
\text { Enter the value of } \mathrm{Q} \text { in } 36 .\end{array}$} & \multicolumn{2}{|l|}{22} & 34 \\
\hline & & \multicolumn{2}{|l|}{$\mathrm{mm}$} & $\mathrm{mm}$ \\
\hline & & \multicolumn{2}{|l|}{8.77} & 0.337 \\
\hline & & \multicolumn{2}{|l|}{20.68} & 5.379 \\
\hline & & \multicolumn{2}{|l|}{32.81} & 13.592 \\
\hline & & \multicolumn{2}{|l|}{71.61} & 46.694 \\
\hline & & \multicolumn{2}{|l|}{97.65} & 70.985 \\
\hline & & \multicolumn{2}{|l|}{108.38} & 81.197 \\
\hline
\end{tabular}


Hydrological Analysis And Peak Discharge Determination

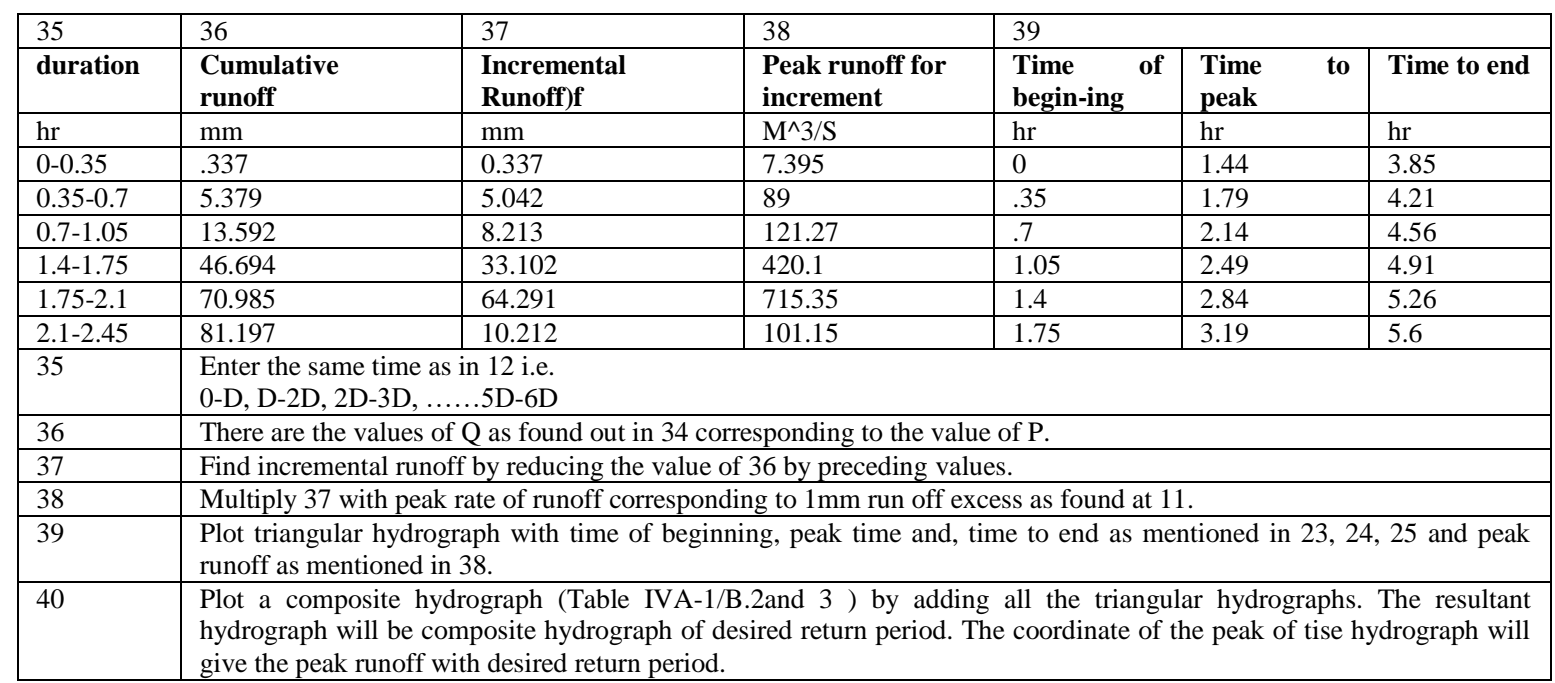

Table 10 Composite Hydrograph

\begin{tabular}{|c|c|c|c|c|c|c|c|}
\hline Time & $\mathbf{Q}_{1}$ & $\mathbf{Q}_{2}$ & $\mathbf{Q}_{3}$ & $\mathbf{Q}_{4}$ & $Q_{5}$ & $\mathbf{Q}_{6}$ & $\mathbf{Q}_{\text {Total }}$ \\
\hline $\mathbf{0}$ & 0 & & & & & & 0 \\
\hline 0.35 & 1.797 & 0 & & & & & 1.797 \\
\hline 0.7 & 3.595 & 21.632 & 0 & & & & 25.227 \\
\hline 1.05 & 5.392333 & 43.264 & 29.475 & $\mathbf{0}$ & & & 78.13133 \\
\hline 1.4 & 7.189833 & 64.896 & 58.95 & 102.475 & 0 & & 233.5108 \\
\hline 1.75 & 6.44 & 86.528 & 88.425 & 204.215 & 173.869 & 0 & 559.477 \\
\hline 2.1 & 5.369 & 77.6 & 117.9 & 305.955 & 347.73 & 24.585 & 879.139 \\
\hline 2.45 & 4.298 & 64.727 & 105.735 & 407.695 & 521.591 & 49.17 & 1153.216 \\
\hline 2.8 & 3.227 & 51.854 & 88.186 & 366.285 & 695.452 & 73.755 & 1278.759 \\
\hline 3.15 & 2.156 & 38.981 & 70.637 & 305.527 & 623.714 & 98.34 & 1139.355 \\
\hline 3.5 & 1.085 & 26.108 & 53.088 & 244.769 & 520.254 & 88.193 & 933.497 \\
\hline 3.85 & $\mathbf{0}$ & 13.235 & 35.539 & 184.011 & 416.794 & 73.5636 & 723.1426 \\
\hline 4.2 & & $\mathbf{0}$ & 17.99 & 123.253 & 313.334 & 58.9342 & 513.5112 \\
\hline 4.55 & & & $\mathbf{0}$ & 62.495 & 209.874 & 44.3048 & 316.6738 \\
\hline \multirow[t]{3}{*}{4.9} & & & & 0 & 106.414 & 29.6754 & 136.0894 \\
\hline & & & & & 0 & 15.046 & 15.046 \\
\hline & & & & & & $\mathbf{0}$ & $\mathbf{0}$ \\
\hline
\end{tabular}

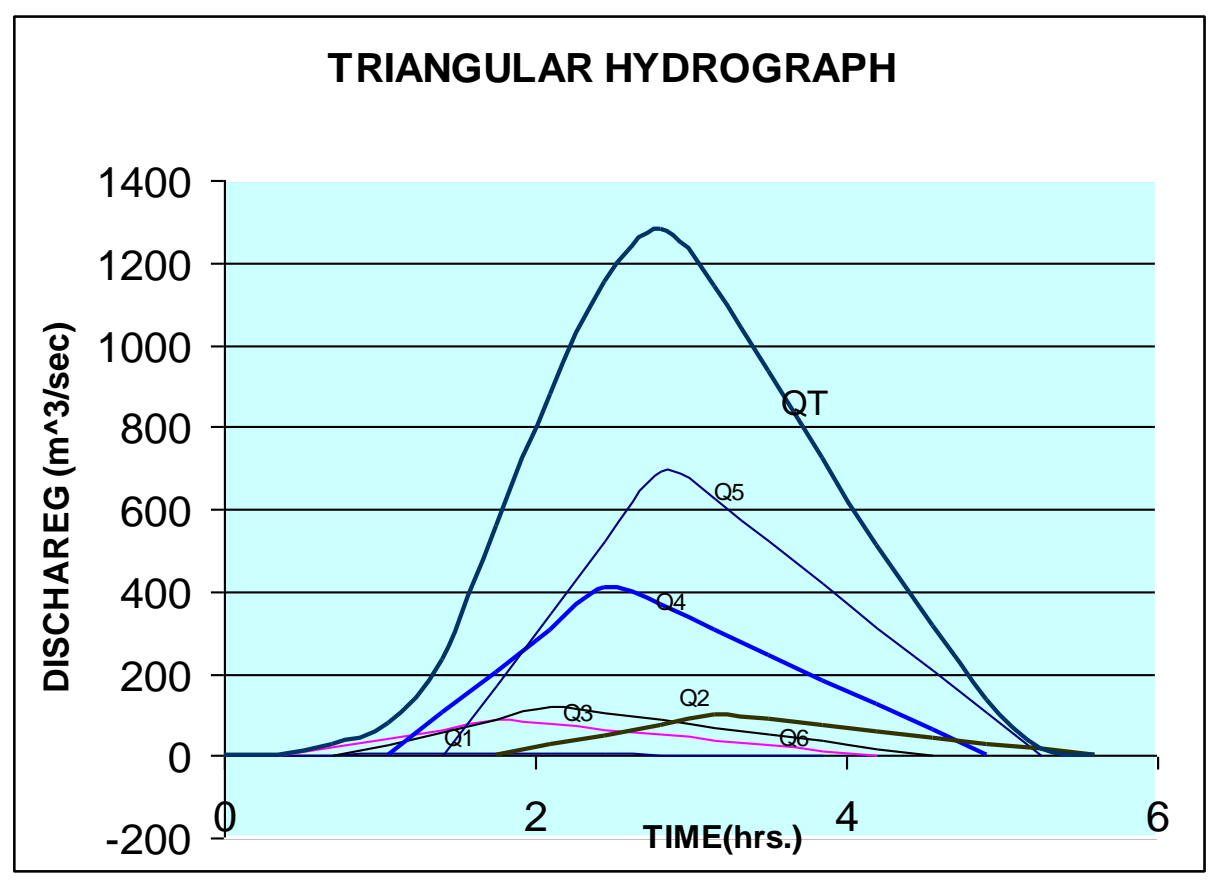

Figure 1 Triangular Hydrograph 


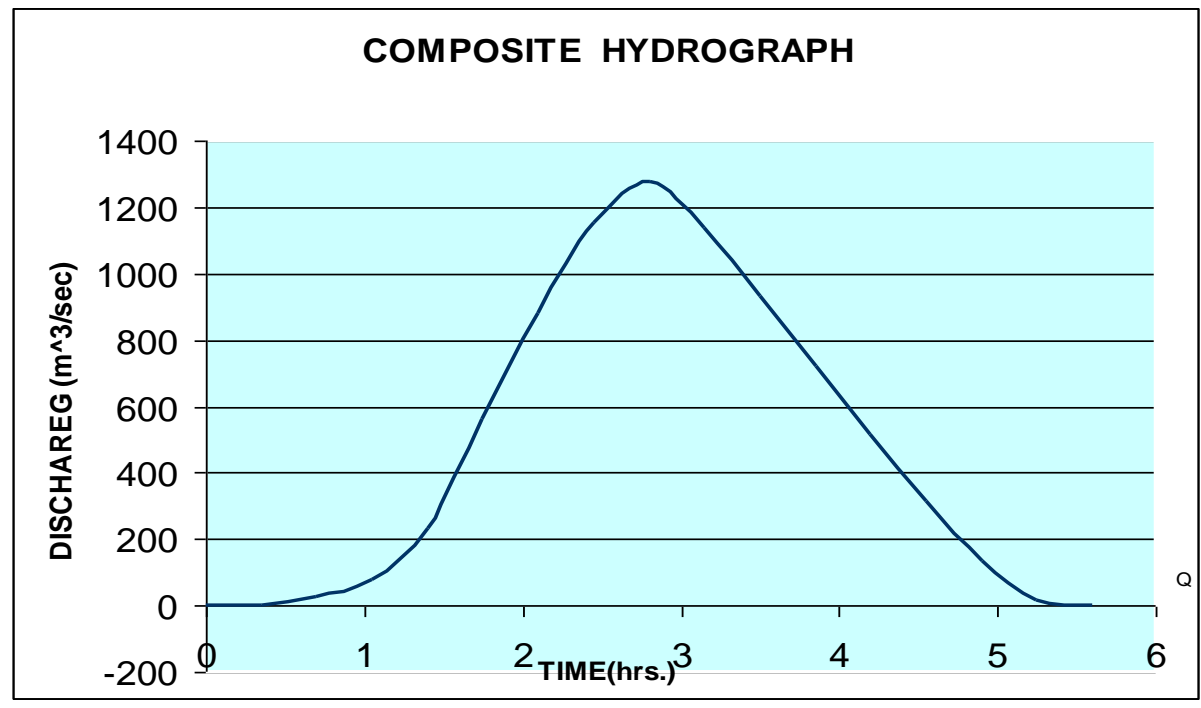

Figure 2 Composite Hydrograph

\subsubsection{Stream Flow Measurement Method}

The catchments of Sager and proposed weir site share common features such as; type of vegetation cover, soil type, agricultural practice and meteorological characteristics like the rainfall amount and distribution periods, and evaporation rates. However, the two catchment differ in some respects, particularly in general slope and catchment size. Therefore, the transposition of the flow recored was worked out based on drainage area ratio. The drainage area of Sagure is 184.4 sq.m and that of the proposed weir site is 150 sq.m respectively, giving a drainage area ratio of 0.8 .Therefore 0.8 plus 0.1 safety factor is used to transpose the Sagure flow to the proposed weir site.

Table 11.4a Summary of maximum discharge

\begin{tabular}{|l|l|l|l|l|l|l|l|l|l|l|l|l|l|}
\hline year & Jan & Feb & Mar & Apr & May & June & July & Aug & Sep & Oct & Nov & Des & Max. flow \\
\hline 1981 & 0.00 & 0.09 & 1.92 & 2.61 & 1.10 & 0.32 & 31.7 & 39.8 & 28.9 & 8.70 & 0.31 & 0.22 & 39.8 \\
\hline 1982 & 0.22 & 0.22 & 0.52 & 2.10 & 1.70 & 0.67 & 1.76 & 6.23 & 2.00 & 1.68 & 0.50 & 0.43 & 6.20 \\
\hline 1983 & 0.13 & 0.27 & 0.32 & 1.52 & 2.35 & 2.26 & 2.44 & 26.56 & 6.46 & 8.66 & 0.78 & 0.43 & 26.6 \\
\hline 1984 & 0.29 & 0.23 & 0.41 & 0.31 & 0.51 & 0.41 & 1.32 & 1.10 & 1.57 & 0.44 & 0.23 & 0.80 & 1.60 \\
\hline 1985 & 0.26 & 0.23 & 0.34 & 0.37 & 1.00 & 0.34 & 1.26 & 1.44 & 1.15 & 0.55 & 0.19 & 0.15 & 1.40 \\
\hline 1986 & 0.11 & 0.15 & 0.31 & 3.10 & 4.10 & 5.10 & 5.44 & 8.11 & 1.84 & 0.94 & 0.28 & 0.17 & 8.10 \\
\hline 1987 & 0.15 & 0.19 & 2.36 & 2.28 & 2.13 & 1.10 & 0.41 & 0.47 & 0.47 & 0.63 & 0.19 & 0.31 & 2.40 \\
\hline 1988 & 0.21 & 2.00 & 0.37 & 0.63 & 0.41 & 0.63 & 22.5 & 39.8 & 3.31 & 1.84 & 0.51 & 0.23 & 39.8 \\
\hline 1989 & 0.19 & 0.41 & 0.63 & 1.21 & 0.58 & 1.32 & 3.03 & 1.70 & 1.20 & 0.71 & 0.31 & 0.47 & 3.00 \\
\hline 1990 & 0.31 & 2.28 & 2.05 & 3.12 & 0.61 & 0.55 & 1.98 & 3.12 & 2.60 & 1.21 & 0.34 & 0.29 & 3.10 \\
\hline 1991 & 0.29 & 0.55 & 1.63 & 1.70 & 0.60 & 0.42 & 1.70 & 3.50 & 2.94 & 0.44 & 0.23 & 0.47 & 3.50 \\
\hline 1992 & 0.41 & 0.34 & 0.21 & 0.51 & 0.71 & 0.80 & 1.27 & 30.1 & 7.70 & 1.20 & 0.37 & 0.34 & 30.10 \\
\hline 1993 & 1.40 & 1.00 & 0.41 & 2.44 & 1.70 & 0.80 & 1.32 & 6.20 & 2.00 & 1.40 & 0.80 & 0.23 & 6.20 \\
\hline 1994 & 1.40 & 0.17 & 0.41 & 0.29 & 0.23 & 0.55 & 17.58 & 14.10 & 0.68 & 0.88 & 0.47 & 0.78 & 17.60 \\
\hline 1995 & 0.21 & 0.18 & 0.89 & 0.51 & 0.41 & 0.28 & 31.70 & 10.30 & 28.9 & 0.55 & 0.79 & 0.80 & 31.70 \\
\hline 1996 & 1.40 & 2.30 & 2.40 & 0.41 & 0.59 & 1.80 & 5.70 & 30.10 & 2.30 & 8.70 & 0.90 & 0.70 & 30.10 \\
\hline 1997 & 0.40 & 0.19 & 0.23 & 1.32 & 0.27 & 1.00 & 1.84 & 1.60 & 0.14 & 1.00 & 0.85 & 0.34 & 1.80 \\
\hline 1998 & 0.47 & 0.80 & 1.57 & 0.62 & 4.10 & 1.21 & 0.20 & 10.90 & 14.4 & 8.41 & 0.80 & 0.11 & 14.40 \\
\hline 1999 & 0.29 & 0.19 & 0.34 & 0.13 & 1.15 & 5.09 & 4.97 & 2.70 & 3.20 & 3.10 & 0.94 & 0.23 & 5.10 \\
\hline 2000 & 0.19 & 0.11 & 0.11 & 0.90 & 0.41 & 5.10 & 31.7 & 39.80 & 28.90 & 8.70 & 0.90 & 0.80 & 39.80 \\
\hline
\end{tabular}

Drainage catchment and rainfall ratio $=0.91$ 
Table 12.4a Transposed maximum discharge

\begin{tabular}{|c|c|c|c|c|c|c|c|c|c|c|c|c|c|}
\hline year & Jan & Feb & Mar & Apr & May & June & July & Aug & Sep & Oct & Nov & Des & Max. flow \\
\hline 1981 & 0.046 & 0.082 & 1.747 & 2.375 & 1.001 & 0.291 & 28.847 & 36.218 & 26.299 & 7.917 & 0.282 & 0.200 & 36.220 \\
\hline 1982 & 0.200 & 0.200 & 0.473 & 1.911 & 1.547 & 0.609 & 1.601 & 5.669 & 1.820 & 1.528 & 0.455 & 0.391 & 5.642 \\
\hline 1983 & 0.118 & 0.246 & 0.291 & 1.383 & 2.138 & 2.056 & 2.220 & 24.169 & 5.878 & 7.880 & 0.710 & 0.391 & 24.210 \\
\hline 1984 & 0.264 & 0.209 & 0.373 & 0.282 & 0.464 & 0.373 & 1.201 & 1.001 & 1.428 & 0.400 & 0.209 & 0.728 & 1.456 \\
\hline 1985 & 0.237 & 0.209 & 0.309 & 0.336 & 0.910 & 0.309 & 1.146 & 1.310 & 1.046 & 0.500 & 0.173 & 0.136 & 1.274 \\
\hline 1986 & 0.100 & 0.137 & 0.282 & 2.821 & 3.731 & 4.641 & 4.950 & 7.380 & 1.674 & 0.855 & 0.255 & 0.154 & 7.371 \\
\hline 1987 & 0.137 & 0.173 & 2.148 & 2.074 & 1.938 & 1.001 & 0.373 & 0.427 & 0.427 & 0.573 & 0.173 & 0.282 & 2.184 \\
\hline 1988 & 0.191 & 1.820 & 0.337 & 0.573 & 0.373 & 0.573 & 20.475 & 36.218 & 3.012 & 1.674 & 0.464 & 0.209 & 36.220 \\
\hline 1989 & 0.173 & 0.373 & 0.573 & 1.101 & 0.527 & 1.201 & 2.757 & 1.547 & 1.092 & 0.646 & 0.282 & 0.427 & 2.730 \\
\hline 1990 & 0.282 & 2.075 & 1.865 & 2.839 & 0.555 & 0.500 & 1.801 & 2.839 & 2.366 & 1.101 & 0.309 & 0.263 & 2.821 \\
\hline 1991 & 0.264 & 0.501 & 1.483 & 1.547 & 0.546 & 0.382 & 1.547 & 3.185 & 2.675 & 0.400 & 0.209 & 0.427 & 3.185 \\
\hline 1992 & 0.373 & 0.309 & 0.191 & 0.464 & 0.646 & 0.728 & 1.155 & 27.391 & 7.007 & 1.092 & 0.337 & 0.309 & 27.390 \\
\hline 1993 & 1.274 & 0.910 & 0.373 & 2.220 & 1.547 & 0.728 & 1.201 & 5.642 & 1.820 & 1.274 & 0.728 & 0.209 & 5.642 \\
\hline 1994 & 1.274 & 0.155 & 0.373 & 0.263 & 0.209 & 0.500 & 15.998 & 12.831 & 0.618 & 0.800 & 0.427 & 0.709 & 16.020 \\
\hline 1995 & 0.191 & 0.164 & 0.809 & 0.464 & 0.373 & 0.254 & 28.847 & 9.373 & 26.300 & 0.500 & 0.719 & 0.728 & 28.850 \\
\hline 1996 & 1.274 & 2.093 & 2.184 & 0.373 & 0.536 & 1.638 & 5.187 & 27.391 & 2.093 & 7.917 & 0.819 & 0.637 & 27.390 \\
\hline 1997 & 0.364 & 0.173 & 0.209 & 1.201 & 0.245 & 0.910 & 1.674 & 1.456 & 0.127 & 0.910 & 0.774 & 0.309 & 1.638 \\
\hline 1998 & 0.428 & 0.728 & 1.428 & 0.564 & 3.731 & 1.101 & 0.182 & 9.919 & 13.100 & 7.653 & 0.728 & 0.100 & 13.100 \\
\hline 1999 & 0.264 & 0.173 & 0.309 & 0.118 & 1.046 & 4.631 & 4.522 & 2.457 & 2.912 & 2.821 & 0.855 & 0.209 & 4.641 \\
\hline 2000 & 0.173 & 0.100 & 0.100 & 0.819 & 0.373 & 4.641 & 28.847 & 36.218 & 26.300 & 7.917 & 0.819 & 0.728 & 36.220 \\
\hline \multicolumn{13}{|c|}{ mean=Qi } & 14.220 \\
\hline \multicolumn{13}{|c|}{$\mathrm{s} . \mathrm{dv}=\sigma n-1$} & 13.420 \\
\hline
\end{tabular}

Table 13.4a Summary of Peak Discharge

\begin{tabular}{|l|l|l|}
\hline Method used & Result & Remarks \\
\hline Rational & $2238 \mathrm{~m}^{3 / \mathrm{s}}$ & It is used for catchments less than 50 sq.km \\
\hline Empirical & $57.67 \mathrm{~m}^{3} / \mathrm{s}$ & Applicable only in the region from which they were developed. \\
\hline United states soil conservation (USSCS) & $1278.56 \mathrm{~m}^{3} / \mathrm{s}$ & $\begin{array}{l}\text { Dredging of lands to widen the weir length from (11m to } 80 \mathrm{~m}) \text { which } \\
\text { is technically difficult. }\end{array}$ \\
\hline Slope area & $290 \mathrm{~m}^{3} / \mathrm{s}$ & $\begin{array}{l}\text { It is between the two extremes of the largest and the lowest. It also } \\
\text { seems an optimal design discharge to implement small scale projects. }\end{array}$ \\
\hline Gauging & $62.2 \mathrm{~m}^{3} / \mathrm{s}$ & $\begin{array}{l}\text { It is so small that, designing with this discharge may be danger. } \\
\text { Because the weir may washed away } \\
\text { Before its design period. }\end{array}$ \\
\hline
\end{tabular}

\subsection{Calculation of Lean Flow}

Stream flow measurement station was established down stream of the proposed weir site. The total catchment area, which drains to this gauging station, is about $184.4 \mathrm{sq} \mathrm{Km}$. Since the gauging is not at the weir site transposing of flow is important.

Transposing of stream flow records to the weir site

1) Froster type 3 method

$$
\sigma=\sqrt{\frac{\sum X^{2}}{n-1}}
$$

$\sigma=$ Standard deviation

$$
\mathrm{Cs}=\frac{\sum X^{3}}{(n-1) \sigma^{3}}
$$

$\mathrm{Cs}=$ coefficient of skew ness

$$
\overline{C s}=\operatorname{Cs}\left(1+\frac{8.5}{n}\right)
$$

$\overline{C S}=$ Adjusted skew ness coefficient 
Table 14 Calculation of $K_{\text {adj }}$

\begin{tabular}{|l|l|l|l|}
\hline \multicolumn{2}{|l|}{ Average base flow by floating } & Transferred value & month \\
\hline Volume $\left(\mathrm{m}^{3} / \mathrm{sec}\right)$ & month & Volume $\left(\mathrm{m}^{3} / \mathrm{sec}\right)$ & April \\
\hline 0.2464 & April & .132 & Feb/march \\
\hline 0.231 & Feb/march & .066 & Oct \\
\hline 0.3 & Oct & .178 & Average $=.126$ \\
\hline Average $=.259$ & & Or \\
\hline
\end{tabular}

$\mathrm{K}_{\mathrm{adj}}=\frac{\text { mean by floting method }}{\text { mean transfered }}$

Kadj is adjustment factor

Therefore $\mathrm{K}_{\mathrm{adj}}=0.259 / 0.126=2.06$

We have used the above parameter to calculate the following table.

Table 15 Lean Flow Analysis

\begin{tabular}{|c|c|c|c|c|c|c|c|c|c|c|c|c|}
\hline Year & Jan & Feb & Mar & Apr & May & Jun & July & Aug & Sep & Oct & Nov & Dec \\
\hline 1981 & 0.00 & 0.00 & 0.00 & 0.55 & 0.05 & 0.05 & 0.41 & 2.02 & 0.73 & 0.37 & 0.0 & 0.00 \\
\hline 1982 & 0.09 & 0.09 & 0.09 & 0.26 & 0.34 & 0.22 & 0.32 & 2.20 & 0.67 & 0.37 & 0.20 & 0.13 \\
\hline 1983 & 0.05 & 0.05 & 0.02 & 0.13 & 0.32 & 0.32 & 0.37 & 1.90 & 2.70 & 0.87 & 0.50 & 0.32 \\
\hline 1984 & 0.23 & 0.17 & 0.17 & 0.19 & 0.17 & 0.04 & 0.31 & 0.51 & 0.41 & 0.19 & 0.20 & 0.98 \\
\hline 1985 & 0.15 & 0.15 & 0.11 & 0.17 & 0.17 & 0.15 & 0.11 & 0.67 & 0.41 & 0.19 & 0.20 & 0.11 \\
\hline 1986 & 0.08 & 0.09 & 0.08 & 0.24 & 0.23 & 0.24 & 0.51 & 1.55 & 0.71 & 0.19 & 0.10 & 0.13 \\
\hline 1987 & 0.11 & 0.11 & 0.15 & 0.34 & 0.21 & 0.29 & 0.11 & 0.29 & 0.29 & 0.19 & 0.20 & 0.15 \\
\hline 1988 & 0.15 & 0.13 & 0.15 & 0.15 & 0.21 & 0.23 & 0.41 & 1.63 & 1.15 & 0.55 & 0.20 & 0.19 \\
\hline 1989 & 0.19 & 0.18 & 0.19 & 0.34 & 0.21 & 0.21 & 0.34 & 0.85 & 0.59 & 0.29 & 0.30 & 0.29 \\
\hline 1990 & 0.29 & 0.29 & 0.44 & 0.51 & 0.34 & 0.29 & 0.51 & 1.32 & 1.00 & 0.34 & 0.20 & 0.23 \\
\hline 1991 & 0.19 & 0.19 & 0.21 & 0.29 & 0.26 & 0.21 & 0.59 & 1.05 & 0.47 & 0.23 & 0.20 & 0.19 \\
\hline 1992 & 0.19 & 0.19 & 0.17 & 0.23 & 0.29 & 0.34 & 0.47 & 0.67 & 0.67 & 0.37 & 0.30 & 0.26 \\
\hline 1993 & 0.23 & 0.38 & 0.19 & 0.19 & 0.41 & 0.29 & 0.41 & 1.40 & 0.71 & 0.41 & 0.20 & 0.21 \\
\hline 1994 & 0.51 & 0.38 & 0.47 & 0.50 & 0.55 & 0.80 & 1.40 & 1.55 & 0.90 & 0.28 & 0.70 & 0.55 \\
\hline 1995 & 0.19 & 0.17 & 0.17 & 0.17 & 0.19 & 0.19 & 0.23 & 1.70 & 0.64 & 0.31 & 0.80 & 0.25 \\
\hline 1996 & 0.17 & 0.17 & 0.16 & 0.19 & 0.19 & 0.23 & 0.31 & 1.84 & 0.55 & 0.37 & 0.30 & 0.25 \\
\hline 1997 & 0.19 & 0.13 & 0.08 & 0.15 & 0.11 & 0.15 & 0.55 & 0.17 & 0.19 & 0.17 & 0.30 & 0.15 \\
\hline 1998 & 0.13 & 0.15 & 0.21 & 0.15 & 0.17 & 0.19 & 0.34 & 2.08 & 0.63 & 0.82 & 0.30 & 0.29 \\
\hline 1999 & 0.21 & 0.13 & 0.13 & 0.26 & 0.09 & 0.09 & 0.11 & 1.00 & 0.52 & 0.59 & 0.20 & 0.11 \\
\hline 2000 & 0.11 & 0.08 & 0.04 & 0.26 & 0.05 & 0.24 & 0.41 & 2.02 & 0.53 & 0.37 & 0.30 & 0.25 \\
\hline mean & 0.17 & 0.17 & 0.16 & 0.26 & 0.23 & 0.24 & 0.41 & 1.32 & 0.72 & 0.37 & 0.28 & 0.25 \\
\hline Std & 0.10 & 0.13 & 0.12 & 0.13 & 0.12 & 0.16 & 0.27 & 0.63 & 0.52 & 0.20 & 0.19 & 0.20 \\
\hline Cs & 1.60 & 2.05 & 1.47 & 1.25 & 0.86 & 2.48 & 2.60 & 0.00 & 3.17 & 1.43 & 1.76 & 2.65 \\
\hline $\mathrm{CS}$ & 2.28 & 2.92 & 2.09 & 1.78 & 1.22 & 3.53 & 3.70 & 0.00 & 4.52 & 2.04 & 2.50 & 3.78 \\
\hline K80\% & 0.73 & 0.60 & 0.80 & 0.80 & 0.85 & 0.60 & 0.62 & 0.84 & 0.60 & 0.80 & 0.70 & 0.62 \\
\hline $\begin{array}{l}\text { Q80\% } \\
\mathrm{g}=\mathrm{Qm} \\
\text { ean+K } \\
80 \% * \\
\text { std }\end{array}$ & .097 & 0.09 & 0.07 & 0.16 & 0.12 & 0.14 & 0.24 & 0.79 & 0.40 & 0.22 & 0.10 & 0.13 \\
\hline
\end{tabular}

\section{Conclusions}

Peak discharge Determination is one of the most important studies for Irrigation projects. The proposed of hydrologic design is to estimate maximum, average or minimum flood which the structure is expected to handle. This estimate has to be made quite accurately in order that the project can function properly. To estimate the magnitude of a flood peak the following alternative methods are available academically. This study was carried out to assess Hydrological Analysis and peak discharge determination. The proposed project of Gusha Temela diversion weir irrigation is predicted to bring both beneficial and adverse impacts on physical, biological and socio-cultural environment. Although the implementation of this diversion weir irrigation project has many benefits, obviously it will also bring a number of adverse impacts to the physical, biological and socio-cultural environment. 
The following conclusions are drawn after the design of Gusha Temela SSIP.

In this study Hydrological analysis has been conducted based on 10years maximum daily rainfall data .The frequency analysis has been carried out by different methods and Log Pearson type III method is adopted .The peak discharge computed by United States Soil Conservation Service (USSCS) method is $1278 \mathrm{~m}^{3} / \mathrm{sec}$. Since this method over estimates the design flood, we adopt the peak discharge calculated by slope -area method.

The peak discharge of Temela River is $290.00 \mathrm{~m}^{3} / \mathrm{s}$ and the weir is designed based on this value. Lean flow of the area is found to be $1.2 \mathrm{~m}^{3} / \mathrm{s}$, The peak duty is found to be $1.31 \mathrm{l} / \mathrm{s} / \mathrm{ha}$ and the available lean flow is sufficient to fulfill the water demand of the crops and downstream requirement. Hence there is no need to construct any storage pond for the designed cropping pattern. Generally the use of irrigation in the study area is found to be essential to alleviate food shortage and to increase source of income of the community.

\section{Acknowledgments}

I am most grateful to Almighty God for blessing, protecting and giving me enough mental and physical strength to make this thesis possible. I must acknowledge and thank all those people who have supported me and had their contributions throughout this period.

\section{References}

[1] Arora K.R (1996), Irrigation, Waterpower and water resource engineering, standard publisher distribution, Naia Sarak Delhi.

[2] Admasu Gebeyehu, 1988: Regional Analysis on Some Aspects of Stream flow Characteristics in Ethiopia. (Unpublished Draft Report). August 1988.

[3] Awulachew, S.B. et al. 2007, Water resources and irrigation development Ethiopia, Ethiopia working paper 123, Addis Ababa, International Water Management Institute.

[4] Baban R. (1995), Design of diversion weirs, small scale Irrigation in hot climate, John Wiely and Sons.

[5] Baharat Singh. (1998), Fundamental of Irrigation Engineering, $8^{\text {th }}$ edition, New Canal and Bros, Roorkee.

[6] Banihabib, M. E., Valipour, M., and Behbahani, S. M. R. (2012). "Comparison of autoregressive static and artificial dynamic neural network for the forecasting of monthly inflow of Dez reservoir.” J. Environ. Sci. Technol., 13(4), 1-14.

[7] Beltrando, G., Camberlin, P., 1993. Inter annual variability of rainfall in the eastern horn of Africa and indicators of atmospheric circulation. Int. J. Climatol. 13, 533-546.

[8] Camberlin, P., 1997. Rainfall anomalies in the Source Region of the Nile and their connection with the Indian Summer Monsoon. Journal of Climate, Vol. 10, pp. 1380 - 1392.

[9] Davis, K, B. Swanson, and D. Amudavi. (2009), Review and Recommendations for Strengthening the Agricultural Extension System in Ethiopia. International Food Policy Research Institute (IFPRI).

[10] Ebissa G. K., Dr K. S. Hari Prasad , and Hitesh Upreti (2017), “Hydrology Final Report on Gondoro Small Scale Irrigation Project", International Journal of Scientific and Engineering Research (IJSER), Vol. 8, No 4, April, pp. 1284-1306

[11] Ebissa G. K.(2017), "Geological study of Gondoro small scale Irrigation project", International Journal of Engineering Development and Research (IJEDR),, Vol. 5, No 2, May, pp. 1148-1156

[12] Ebissa G. K.( 2017), "Agronomy Study on Small Scale Irrigation Project", International Journal of Engineering Development and Research (IJEDR), Vol. 5, No 2, , May, pp.1157-1167

[13] Ebissa G. K. (2017), "Hydrology of Small Scale Irrigation Project", International Journal of Engineering Development and Research (IJEDR), Vol.5, Issue 2, May, pp.1176-1198

[14] Ebissa G. K.( 2017), "Estimation of Open Channel Roughness by using Gradual Varied Flow Profiles", International Journal of Science and Research (IJSR), Vol. 6, No 5, May, pp. 1295 - 1304

[15] Ebissa G. K. (2017), "Environmental Impact Assessment and their Mitigation measures of Irrigation Project, International Journal of Innovative Science and Research Technology (IJISRT), Vol. 2, No 5, May, pp: 186-193.

[16] Ebissa G. K. (2017), "Hydrologic Analysis and peak discharge determination", International Journal of Engineering Development and Research (IJEDR), Vol.5, No 2, May pp.1258-1286.

[17] ERA (Ethiopian Roads Authority), 2002: Drainage Design Manual, Hydrology.

[18] Estevez, J., Gavilan, P., and Berengena, J. (2009). "Sensitivity analysis of a Penman-Monteith type equation to estimate reference evapotranspiration in southern Spain." Hydrol. Process., 23(23), 3342-3353.

[19] FAO (1983), Guide lines for predicting crop water requirement, irrigation and drainage paper 24, FAO, Rome.

[20] FAO (1986), Yield response to water, irrigation and drainage paper 33, FAO, Rome.

[21] FAO (1998): CROPWAT for Windows, User-Guide, Version 4.3.

[22] Food and Agriculture Organization, homepage. www.fao.org (01-01-2008)

[23] FAO (Food and Agricultural Organization of the United Nations) (2014), Food and Agriculture organization of the United Nations, Global information and Early warning system country brief. December 2014.

[24] Fiddes D, 1977: Flood estimation for small East African rural catchments, Proceeding Institution of Civil Engineers, Part 2, 63, 2134 (1977)

[25] Garg S.K (1996), Irrigation engineering and Hydraulics structure, $12^{\text {th }}$ editon, Kahanna publishes distributors, Delhi.

[26] Haile, T., 1986. Climatic variability and support feedback mechanism in relation to the Sahelo-Ethiopian droughts. M.Sc. Thesis in Meteorology, Department of Meteorology, University of Reading, U.K. pp.119-137

[27] Haile, A.M. 2007, A tradition in transition, water management reforms and indigenous spate irrigation systems in Eritrea. Leiden, Taylor and Francis/Balkema. Ph. D. thesis. Wageningen University.

[28] K. Subramanya (2006), Engineering Hydrology, Second Edition, Tata McGraw Hill; New Delhi

[29] Mersha, E., 1999. Annual rainfall and potential evapotranspiration in Ethiopia. Ethiopian Journal of Natural Resources 1(2): 137154.

[30] Michael A.M (1979), Irrigation Theory and Practice, Vikas publishing house pvt. Ltd. New Delhi.

[31] MOWR 2004, National water development report for Ethiopia, United Nations Educational, Scientific, and Cultural Organization World Water Assessment Program.

[32] Mutreja, K.N. (1986) Applied Hydrology. 959 p. Tata McGraw Hill. 
[33] NMSA (National Meteorology Service Agency), 1996. Climatic and Agro climatic Resources of Ethiopia. Vol. 1, No. 1. National Meteorology Service Agency of Ethiopia, Addis Ababa.137 pp.

[34] Rahimi, S., Gholami Sefidkouhi, M. A., Raeini-Sarjaz, M., and Valipour, M. (2014). "Estimation of actual evapotranspiration by using MODIS images (A case study: Tajan catchment).” Arch. Agron. Soil Sci., 1.

[35] Ray K.Linsley, Jr (1986), Hydrology for Engineers, McGraw-Hill Inc. $3^{\text {rd }}$ Edition.

[36] Sharsarabude S.R (1994), Irrigation engineering and Hydraulics structures, $6^{\text {th }}$ edition, S.K. Katrina, Sons, Delhi.

[37] Shaw, Elizabeth M., 1988: Hydrology in Practice. International Van Nostrand Reinhold.

[38] Schrader, F., et al. (2013). "Estimating precipitation and actual evapo transpiration from precision lysimeter measurements." Procedia Environ. Sci., 19, 543-552.

[39] S.K. Garg (2005), Hydrology \& Water Resources Engineering; $13^{\text {th }}$ revised edition ; New Delhi

[40] Subramanian K. (1984), Engineering Hydrology, 2nd edition Tata McGraw-Hill

[41] Publishing co. Ltd, New Delhi.

[42] Taddesse, T., 2000. Drought and its predictability in Ethiopia. In: Wilhite, D.A. (Ed.), Drought: A Global Assessment, Vol. I. Routledge, pp. 135-142.

[43] Tesfaye, K., 2003. Field comparison of resource utilization and productivity of three grain legumes under water stress. Ph.D. thesis in Agro meteorology, Department of Soil, Crop and Climate Sciences, University of the Free State, South Africa.

[44] Teshome, W. 2003, Irrigation practices, state intervention and farmers' life-worlds in drought-prone Tigray, Ethiopia. Ph. D. thesis. Wageningen University.

[45] Tian, H., Wen, J., Wang, C. H., Liu, R., and Lu, D. R. (2012). "Effect of pixel scale on evapotranspiration estimation by remote sensing over oasis areas in north-western China." Environ. Earth Sci., 67(8), 2301-2313.

[46] Tian, F., Qiu, G., Yang, Y., Lu, Y., and Xiong, Y. (2013). "Estimation of evapotranspiration and its partition based on an extended three temperature model and MODIS products." J. Hydrol., 498, 210-220.

[47] Tilahun, K, 1999. Test homogeneity, frequency analysis of rainfall data and estimate of drought probabilities in Dire Dawa, Eastern Ethiopia. Ethiopian Journal of Natural Resources 1(2) 125-136.

[48] US Army Corps of Engineers (1993). Hydrologic Frequency Analysis, Engineer Manual 1110-2-1415.

[49] USDA Soil Conservation Service (1972) National engineering handbook: section 4. Hydrology, Chapters 4-10 USDA-SCS, Washington, DC

[50] Valipour, M. (2014a). "Analysis of potential evapotranspiration using limited weather data." Appl. Water Sci., in press.

[51] World Bank (2008), Ethiopia at a glance. Washington, D.C.: World Bank.

[52] Xu, C. Y., and Chen, D. (2005). "Comparison of seven models for estimation of evapotranspiration and groundwater recharge using lysimeter measurement data in Germany." Hydrol. Process., 19(18), 3717-3734. 